\title{
Analysis of the Dimensions of The Profile of Law Doctorate Graduates from Peruvian Universities
}

\author{
Hugo GONZÁLEZ \\ Universidad Autónoma del Perú, Lima, Perú \\ hugo_augencio@hotmail.com
}

Received date:4 February 2021; Accepted date:16 July 2021; Published date: 21 September 2021

Copyright (C) 2021. Hugo GONZÁLEZ. Distributed under Creative Commons Attribution 4.0

International CC-BY 4.0

\begin{abstract}
This research analyzes the dimensions of the profile of law doctorate graduates from Peruvian universities that have been licensed by the National Superintendence of Higher Education (Sunedu). A qualitative analysis has been carried out through the Atlas ti program of the 15 programs licensed in 2020 . The dimensions include legal research, critical thinking, the alliances they have established, humanistic training, counseling, university teaching, legal training, management of legal plans, responsibility or social projection. According to the profiles studied, the most relevant categories are legal research and university teaching.
\end{abstract}

Keywords: Graduate Profile, Legal Research, University Teaching, Legal Training, Management.

\section{Introduction}

Universities fulfill main roles: training, social projection and research. In this scenario, postgraduate schools train highly specialized professionals in a specific area, encourage the development of science and social projection in order to know about and solve environmental problems based on research, as well as to strengthen the "university-society" link (Rueda, Acosta and Cueva, 2020). This relationship must generate a social impact in order to meet the needs of the communities (Alzate, Gutiérrez and Orozco, 2018). Universities boost the education of highly trained researchers in a specific discipline (Angarita and Mateo, 2011). They train professionals not only on the understanding of theories, but also on their creation and application in the development of various activities: teaching, research or project management, advisory or consultancy, etc.

Programs are developed based on a syllabus that responds to university purposes and specifies the skills defined in the doctoral profiles (admission, graduation), which are carried out through a teaching-learning process by means of active teaching strategies and relevant assessment systems for this process. In this context, research courses are the most relevant due to the nature of the $\mathrm{PhD}$, which involves developing high-quality research. 
The profile of law graduates from doctoral programs by Peruvian Universities that have been licensed by the National Superintendency of Higher University Education (Superintendencia Nacional de Educación Superior Universitaria, Sunedu) is analyzed within this framework. The skills or capacities that are proposed in the professional training profile are construed with an emphasis on the research, which must be relevant and genuine. These scientific imperatives are also legal as established by the European system for the level of a PhD in Law (Llopis, 2019), which

is in accordance with Peruvian University Law no. 30220 where it is established that the said studies are based on research and are intended to develop the scientific knowledge of the highest level (Art. 43.3).

The Article systematizes the profile's components or capacities of PhD graduates in law, since there are no previous investigations that have systematized such information. In the development of the research, the following questions are formulated: which categories have the greatest presence and relevance in the graduation profile of graduate law schools in Peruvian Universities? Is there any articulation between the studied categories of the graduates' profiles? Which competencies need to be strengthened or developed in the Law doctoral programs at Peruvian Universities?

\section{Background and Rationale}

\section{Previous Contributions}

The profile and professional competencies are planned and made explicit in a syllabus that responds to a certain context, time, society type, purposes of the institution or university; and didactic, pedagogical, philosophical, as well as sociological principles that have been promoted since the 1960s (Vila and Hernández, 20113.)

The professional profile is not only studied in the legal field, but in other specialties or branches as well. For example, the professional doctoral profile (in physical education) has been investigated, where it has been concluded that graduates have greater possibilities of entering higher levels of education and participating in scientific research (Manta, Sandreschi, Cardoso, Benedetti, Farias, Resende and Nascimento, 2019). Other studies emphasize the capacities that $\mathrm{PhD}$ graduates or $\mathrm{PhD}$ students with research skills (research competencies) must develop, transfer knowledge and internationalize the training of these programs (Jiménez-Ramírez, 2017). An element that corresponds to these approaches is research capacity as a transversal axis that encourages scientific knowledge.

Teaching competencies are specified within the profile, and in postgraduate studies, it is considered that their quality depends on the quality of the professors who teach (Kleck and Mims, 2017). Teachers of postgraduate degrees are required to certify or possess "a PhD title" (Hermida, 2018, p. 197). Likewise, a high percentage of postgraduates (85\%) are engaged in teaching and/or research (Fiftal, 2016). These areas are relevant to postgraduate programs because they aim to maintain the quality of this level.

In Latin America, the dogmatic legal model continues to prevail in the postgraduate legal research, which has made the development of legal research impossible. In this sense, it is urgent to consider the contributions of traditional research, taking into consideration contemporary conceptions that include the complexity of reality and its interrelation with the other social sciences (Pavo, 2015).

In this scenario, legal research, apart from prioritizing the development of the positivist conception, also distances itself from other social sciences, which prevents it from obtaining a global or general understanding of legal phenomena. It has also segmented or isolated the legal study from its socio-cultural context (Witker, 2008).

\section{Fundamentals of the profile}

The professional profile is defined as "a model, an idealization of the characteristics, knowledge, and skills that a graduate must possess" (Vila and Hernández, 2013, p. 127). It describes the graduate's characteristics or competences in order to respond to a 
certain social context according to the university or institution that proposes it. It is a bridge or link between the university and society.

In law, the competencies of a lawyer consist of three components: conceptual, procedural and attitudinal (Zolezzi, 2017). A proposal that matches those components was established by the UNESCO, through Delors (1996) who considers that the competencies are developed into types of knowledge: cognitive, action, coexistence and the know-how.

The key axes in the training of the $\mathrm{PhD}$ graduate focus on research competences, the practice of interdisciplinarity, internationalization, as well as development or interaction with companies (JiménezRamírez, 2017). It implies that doctoral training is based on training and research requirements, and on the performance or interaction with the business or work environment.

In Latin America, the key competences in the training of lawyers have been specified as: the interpretation, argumentation, and knowledge of social problems with the application of theories, norms, and axioms for the understanding of law in line with work, cultural and social aspects (Sanromán and Morales, 2016).

\section{The competences of the PhD}

Changes in education, which have also operated in doctoral programs (in Europe), focused on research in various branches of knowledge with interdisciplinary aspects, with the collaboration of other entities (national and international) that carry out research activities, and establish specific lines for research in doctoral theses, their contribution to society; as well as the organization or structure for the organization of the research lines. In this process, those who direct and guide doctoral research play an important role. Since this research must be related to the companies' participation, a particular role is performed by directors, tutors or thesis advisers who must prove a research focus. The same applies for those who teach. This is in addition to the mobility of $\mathrm{PhD}$ graduates and their internationalization, exchanges, and stays in other countries (Jiménez and Sevillano, 2017). These actions allow for coordination between the universities, the company, and the State for the planning and execution of research projects that respond to national and international social demands.

What has been previously described about the European system is related to the Chilean context in Latin America, where a series of changes has been identified in the consolidation of the university system, consistent with what happens in other aspects regarding legal training: "competition in the market, the appearance of rankings, specialized research due to the demands of doctoral training, the recruitment of the best professors and researchers from law schools and access to accreditation as a mechanism to ensure teaching quality" (Muñoz, 2014, p.10). This process improves the quality of postgraduate education because "it judges the value and merit, as well as the correct suitability of the peer evaluators" (Bozzo and Remeseiro, 2017, p.3) which allows an objective evaluation of the criteria that certify the quality of these programs.

The schools that are in "the best ranking require candidates who have a postgraduate degree, preferably a $\mathrm{PhD}$ " (Solari, 2012, p. 711). In this sense, legal education adapts to the demands of legal markets and globalization the same as in "American and foreign" contexts (Manley, 2019, p. 399). This same case is established regarding teachers who have a $\mathrm{PhD}$ in a science other than law, apart from the degree in a legal discipline (Pérez, 2018), an aspect that enriches teacher training to respond to a competitive market and to educate graduate students efficiently.

Doctoral competences focus their interest on the development of research, for example, the European system establishes, by means of regulations, the understanding and mastery of skills and research methods related to an area or discipline; likewise, the realization of original research, the practice of effective communication with the scientific community, the development of science and technology that responds to the knowledge society (Jiménez, 2017). 


\section{Research in the PhD}

Doctoral training in law emphasizes the development of research in various contexts. For example, in the German system, the "program consists of the completion of a doctoral thesis under the supervision of a professor for two or three years. During this time and for a maximum of six years, the candidate can receive a temporary contract as an academic employee or junior research assistant" (Pérez Hurtado, 2018, p. 280). A similar situation occurs in the United States, where "the most advanced academic degree is aimed at those interested in a teaching or research career" (Vides, Gómez \& Pérez, 2011, p. 363). The European system takes into consideration specialization in research (Jiménez-Ramírez, 2017).

The scientific competences in a $\mathrm{PhD}$ program include: disciplinary sciences that develop quality research with an international impact to contribute to the scientific community; methodological sciences with an efficient mastery of the quantitative and qualitative to carry out high-level research; as well as instrumental competences that involve evaluating and applying mixed research techniques (quantitative and qualitative) to improve the understanding of the phenomena being investigated (Núñez-Valdés and González, 2019).

Likewise, general and specific competences must be considered in national and international legal training (Clavijo, 2014). The former develops teamwork, mastery of ICT, the ability to adapt, the practice of ethics, etc. They are transversal to all specialties. The specific ones require the domain of specific capacities such as argumentation and legal writing, oral litigation, resolution of judicial conflicts, etc.

The specific legal competencies for Latin American Tuning comprise an average of 24 competencies (Clavijo, 2014), including: legal reasoning and argumentation, defense of people's interests, legal ethics, and legal decision-making. Other competences are related to the application of legal scientific research criteria, work in interdisciplinary teams, and command of a foreign language.
Competencies must be developed through the teaching of integrative research for a holistic training that integrates the legal phenomenon with the regulations, social facts and context (Witker, 2008). This proposal has been systematized in the $\mathrm{PhD}$ in a specific subject (Legal Situation of the Entrepreneur of the Division of Postgraduate Studies of the UNAM) that includes the following elements: problem, main aspects, what has been studied, relationships between the main elements, legislation (national and international), and legal solution. It was developed through the virtual platform, where the generation of products or argumentative texts investigation (Cázares, 2017) that allow the development of investigative, argumentative and creative capacities is evidenced.

From the assumption of the competences, the development of the doctoral thesis is established, which must be an original work and contribute to the field of science (Angarita and Mateo, 2011). In this

sense, "the thesis must give an account of originality and deep analysis of existing and generated knowledge. The $\mathrm{PhD}$ student must demonstrate capacities for the scientific research, and have a good structure and organization. The research needs to be sustained and socialized" (Grarcés-Prettel and Santoya-Montes, 2013, pp. 290-291).

In Peru, there are some studies on doctoral theses. However, in the case of education, the production of theses from 2009-2013 have been investigated, where a prevalence for themes regarding "teaching-learning methods and the curriculum with more emphasis on higher education through quantitative work" has been found (Díaz and Sime, 2016, p. 6). In the medical field, the scientific activities of doctors in medical sciences and health were studied, concluding that only one in four graduates is a researcher or has published scientific manuscripts, and two out of ten have published their doctoral research work (Herrera-Añazgo and Alhuay -Quispe, 2020). In this regard, a study was carried out on research in graduate law schools and it was found that there is no homogeneity in 
the research courses; there is a greater predominance of thesis seminars and less emphasis on the preparation and publication of scientific articles (González, 2018).

From the legal field, a new University Law was approved in 2014 where it is specified that PhDs "are academic studies based on research. They are intended to develop knowledge at the highest level. A minimum of sixty-four (64) credits must be completed, with mastery of two (2) foreign languages, one of which can be substituted for a native language" (University Law, 2014 , p. 22). Also, article No. 45.5 establishes that in order to obtain the degree, a thesis of excellent academic and original rigor must be defended. These legal approaches have made it

possible to improve the development of research in Peru because they have met the basic conditions, including research.

In this context, the profiles also take into consideration critical thinking, and humanistic training. The first involves some domains such as "to analyze, organize, reason, argue, question, ask, evaluate, make decisions, act and commit" (Bezanilla, Poblete, Fernández, Arranz and Campo, 2018, p. 111). It also involves comprehensive university education as a human being. While humanistic training "provides the essential cognitive elements to better understand the world, to obtain an aesthetic education together with the refinement of sensitivity, and the elevation of moral and ethical qualities" (Sánchez and Pérez, 2017, p. 267). Humanistic and critical training avoid mechanization in educational training, since it allows the student to criticize, and evaluate reality with responsibility, sensitivity and integration among individuals.

\section{Method}

The graduation profile of $\mathrm{PhD}$ programs in law, licensed by Sunedu, has been considered for this analysis. A qualitative analysis by categories has been carried out through Atlas ti on the texts that have been published on its websites. The source was consulted from February to April 2020.

The study is carried out based on the following categories: research, critical thinking, alliances, humanistic education, counseling, teaching, legal training, legal project management, and social projection.

The programs were consulted on the Sunedu portal where $25 \mathrm{PhD}$ programs in law were identified, but only 15 that have made their profiles explicit through the portal have been analyzed. 
Table 1: Graduate profile of $\mathrm{PhD}$ programs in law

\begin{tabular}{|c|c|c|c|}
\hline \multirow[t]{2}{*}{ No. } & \multirow[t]{2}{*}{ University } & \multicolumn{2}{|c|}{ Graduation profile } \\
\hline & & Yes & No \\
\hline 1 & $\begin{array}{l}\text { Universidad Nacional del Altiplano } \\
\text { (National University of the Altiplano) }\end{array}$ & $x$ & \\
\hline 2 & $\begin{array}{l}\text { Universidad Antenor Orrego } \\
\text { (Antenor Orrego University) }\end{array}$ & & $\mathrm{x}$ \\
\hline 3 & $\begin{array}{l}\text { Universidad San Ignacio de Loyola } \\
\text { (Saint Ignatius of Loyola University) }\end{array}$ & & $x$ \\
\hline 4 & $\begin{array}{l}\text { Universidad Privada de Tacna } \\
\text { (Private University of Tacna) (Law) }\end{array}$ & & $\mathrm{x}$ \\
\hline 5 & $\begin{array}{l}\text { Universidad de Piura } \\
\text { (University of Piural }\end{array}$ & & $\mathrm{x}$ \\
\hline 6 & $\begin{array}{l}\text { Universidad Nacional de San Agustin de Arequipa } \\
\text { (National University of San Agustin of Arequipa) }\end{array}$ & $x$ & \\
\hline$\overline{7}$ & $\begin{array}{l}\text { Universidad Nacional de la Amazonia Peruana } \\
\text { (National University of the Peruvian Amazon) }\end{array}$ & $x$ & \\
\hline 8 & $\begin{array}{l}\text { Universidad Católica de Santa María } \\
\text { (Catholic University of Santa Maria) }\end{array}$ & $x$ & \\
\hline 9 & Universidad del Norte SAC & & $\mathrm{x}$ \\
\hline 10 & Universidad César Vallejo SAC & $x$ & \\
\hline 11 & $\begin{array}{l}\text { Universidad Nacional San Antonio Abad del Cusco } \\
\text { (National University of Saint Anthony the Abbot of Cusco) }\end{array}$ & $x$ & \\
\hline 12 & $\begin{array}{l}\text { Universidad Nacional HermilioValdizán de Huánuco } \\
\text { (HermilioValdizán de Huánuco National University) }\end{array}$ & $x$ & \\
\hline 13 & $\begin{array}{l}\text { Universidad de Huánuco } \\
\text { (University of Huánuco) }\end{array}$ & & $\bar{x}$ \\
\hline 14 & $\begin{array}{l}\text { Universidad Privada de Tacna (Penal and Criminal Policy) } \\
\text { (Private University of Tacna) }\end{array}$ & $x$ & \\
\hline 15 & $\begin{array}{l}\text { Universidad Nacional de Trujillo } \\
\text { (National University of Trujillo) }\end{array}$ & & $\bar{x}$ \\
\hline 16 & $\begin{array}{l}\text { Universidad Nacional Santiago Antúnez de Mayolo } \\
\text { (Santiago Antúnez de Mayolo National University) }\end{array}$ & $x$ & \\
\hline 17 & $\begin{array}{l}\text { Universidad Nacional de Huancavelica } \\
\text { (National University of Huancavelica) }\end{array}$ & & $x$ \\
\hline 18 & $\begin{array}{l}\text { Universidad Nacional José Faustino Sánchez Carrión } \\
\text { (José Faustino Sánchez Carrión National University) }\end{array}$ & $x$ & \\
\hline 19 & $\begin{array}{l}\text { Universidad Nacional de Piura } \\
\text { (National University of Piura) }\end{array}$ & $x$ & \\
\hline 20 & $\begin{array}{l}\text { Pontificia Universidad Católica del Perú } \\
\text { (Pontifical Catholic University of Peru) }\end{array}$ & $x$ & \\
\hline 21 & $\begin{array}{l}\text { Universidad Andina del Cusco } \\
\text { (Andean University of Cusco) }\end{array}$ & & $\mathrm{x}$ \\
\hline 22 & $\begin{array}{l}\text { Universidad de Huánuco } \\
\text { (University of Huánuco) }\end{array}$ & & $\bar{x}$ \\
\hline 23 & $\begin{array}{l}\text { Universidad San Martin de Porres } \\
\text { (San Martin de Porres University) }\end{array}$ & $\mathrm{x}$ & \\
\hline 24 & $\begin{array}{l}\text { Universidad Nacional Federico Villarreal } \\
\text { (Federico Villarreal National University] }\end{array}$ & $x$ & \\
\hline 25 & $\begin{array}{l}\text { Universidad Nacional de San Marcos } \\
\text { (National University of San Marcos) }\end{array}$ & $x$ & \\
\hline
\end{tabular}

Note. Prepared by the author based on data from Sunedu, 2020. 
The table above shows that out of the 25 graduate $\mathrm{PhDs}$ that have been consulted on the Sunedu website, only 15 universities have specified their graduation profile from February to April of this year.

\section{Results}

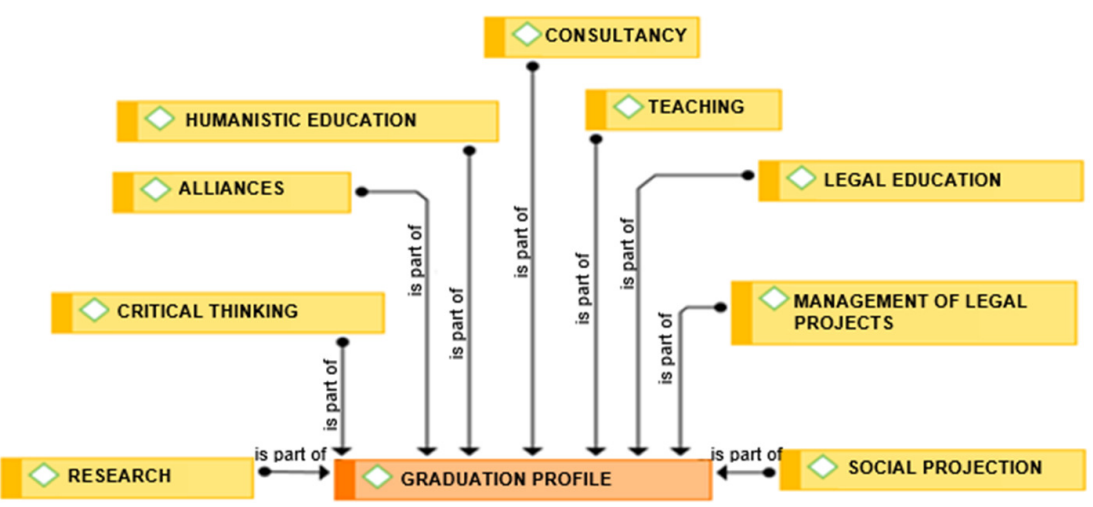

Figure 1: Categories of the graduation profile of graduate law schools in Peruvian Universities

Prepared by the author based on the information analyzed

Figure 1 shows the categories identified in the graduation profiles: counseling, teaching, legal education, management of legal projects, social projection, research, critical thinking, alliances, and humanistic education. Research has a higher prevalence.

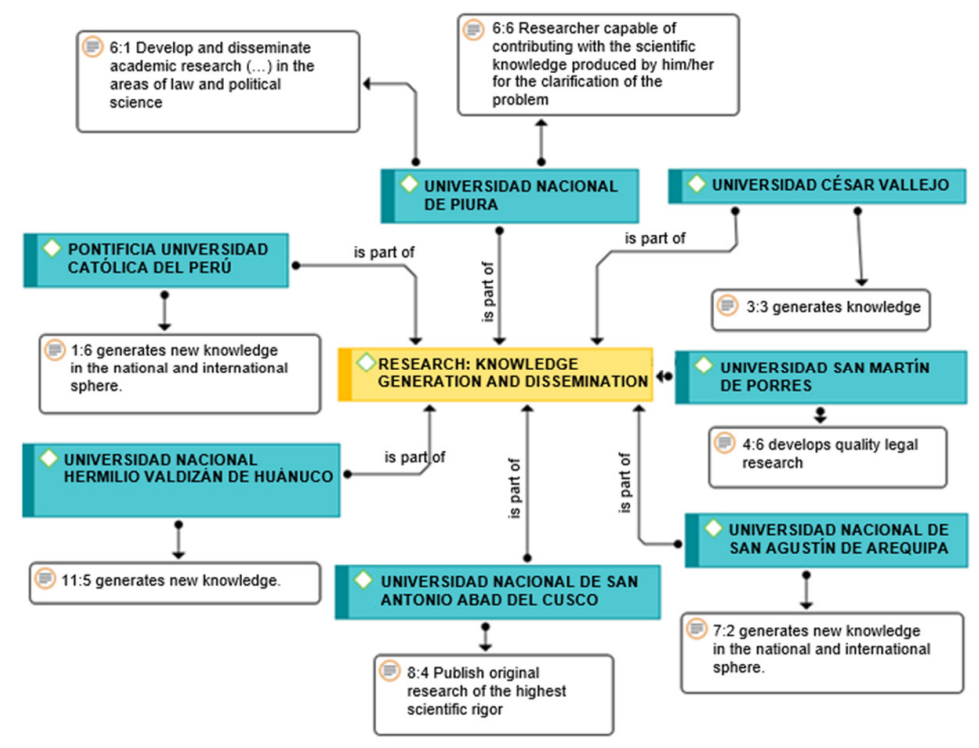

Figure 2: Research: generation and dissemination of knowledge

Note. Prepared by the author based on the information analyzed 
In figure 2, the knowledge generation and dissemination of the graduate law schools in Peruvian Universities are presented. Of the fifteen schools analyzed, seven made this category explicit, emphasizing the ability to investigate and provide scientific knowledge to clarify problems related to law or political science (Universidad Nacional de Piura), generate scientific knowledge with an international scope (Pontificia Universidad Católica del Perú, César Vallejo, San Agustín de Arequipa, HermilioValdizán de Huánuco), and prepare and publish quality legal research (Universidad San Martín de Porres y San Antonio Abad del Cusco).

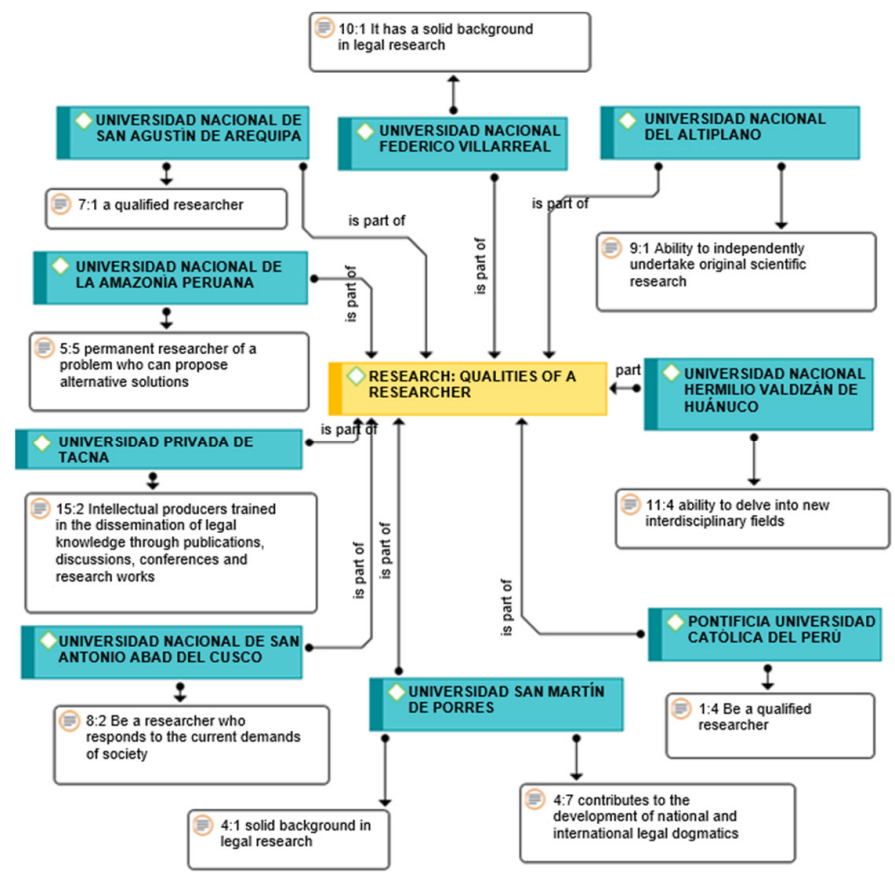

Figure 3: Research: qualities of the researcher

Note. Prepared by the author based on the information analyzed

The preceding figure expresses the qualities of $\mathrm{PhD}$ graduates researchers. It is specified that they must have a solid training in law research (Universidad Nacional Federico Villarreal, San Martín de Porres), are prepared to develop original scientific research (Universidad Nacional del Altiplano), have the ability to develop interdisciplinary research (Universidad HermilioValdizán de Huánuco), are qualified researchers (Pontificia Universidad Católica del Perú, San Agustín de Arequipa) respond to the demands of society (Universidad San Antonio Abad del Cusco), are intellectual producers to disseminate knowledge (Universidad Privada de Tacna) and propose alternative solutions (Universidad Nacional de la Amazonía Peruana). 


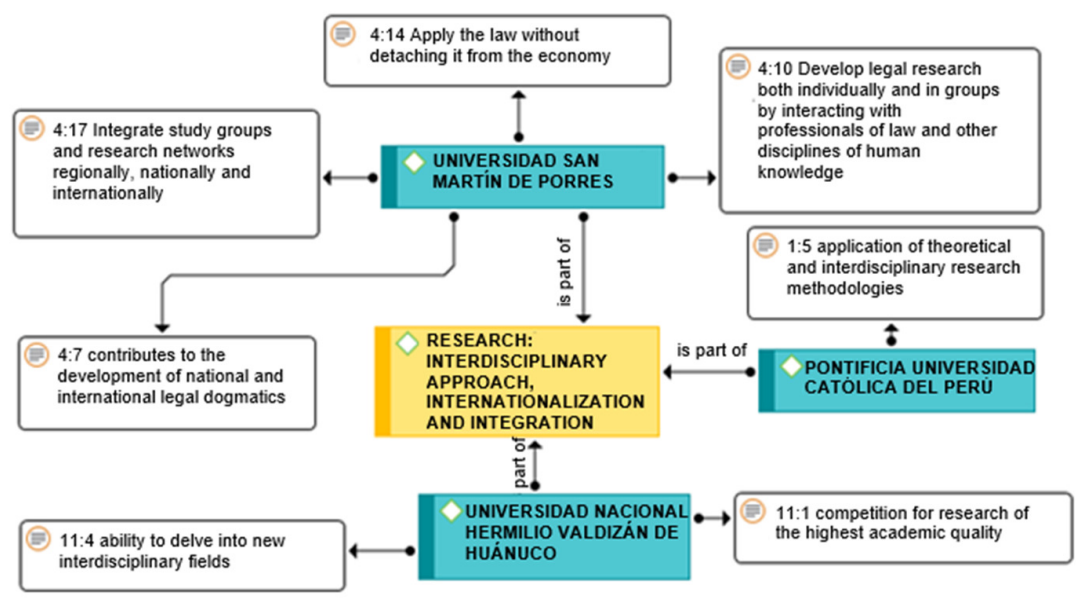

Figure 4: Research: interdisciplinary, international and integration approach Note. Prepared by the author based on the information analyzed

Figure 4 shows that some universities develop the legal discipline in relation to other specialties, which allows for acting in new interdisciplinary areas (Pontificia Universidad Católica del Perú, Universidad Nacional HermilioValdizán de Huánuco); integrating with other groups or professionals, and generating research networks to develop science at a regional, national and international level (Pontificia Universidad Católica del Perú, Universidad San Martín de Porres).

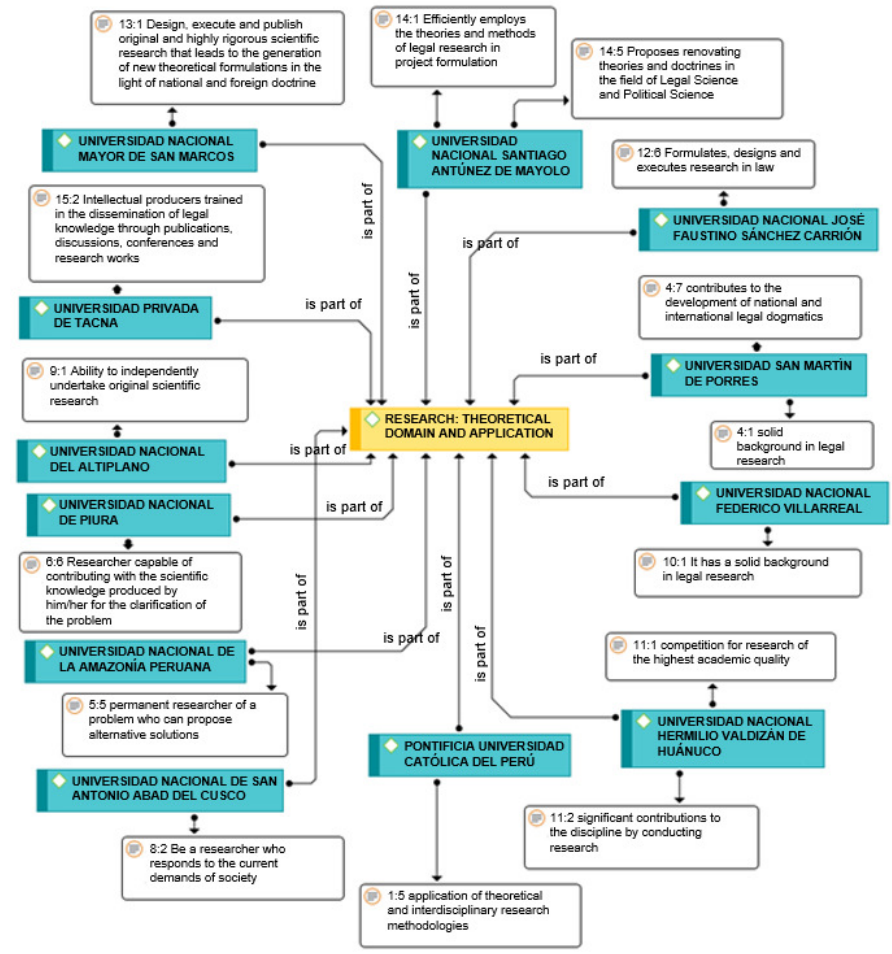

Figure 5: Research: domain and application

Note. Prepared by the author based on the information analyzed 
Figure 5 specifies the solid, high-quality legal education that the graduate must have (Universidad San Martín de Porres, Federico Villarreal, Hermilio Valdizán de Huánuco). Likewise, the graduate designs, executes, and applies the methodologies or theories of legal research in the field of law that respond to the demands and problems of society within the national and international scope (Universidad José Faustino Sánchez Carrión, Católica del Perú,
Santiago Antúnez de Mayolo, Universidad Mayor de San Marcos, Privada de Tacna, Universidad Nacional del Altiplano, Universidad de la Amazonía Peruana, San Antonio Abad del Cusco y San Martín de Porres). In this case, there is a systematic process that includes: preparation in legal research, design and development; and finally, the publication or application to respond to problems or requirements of society.

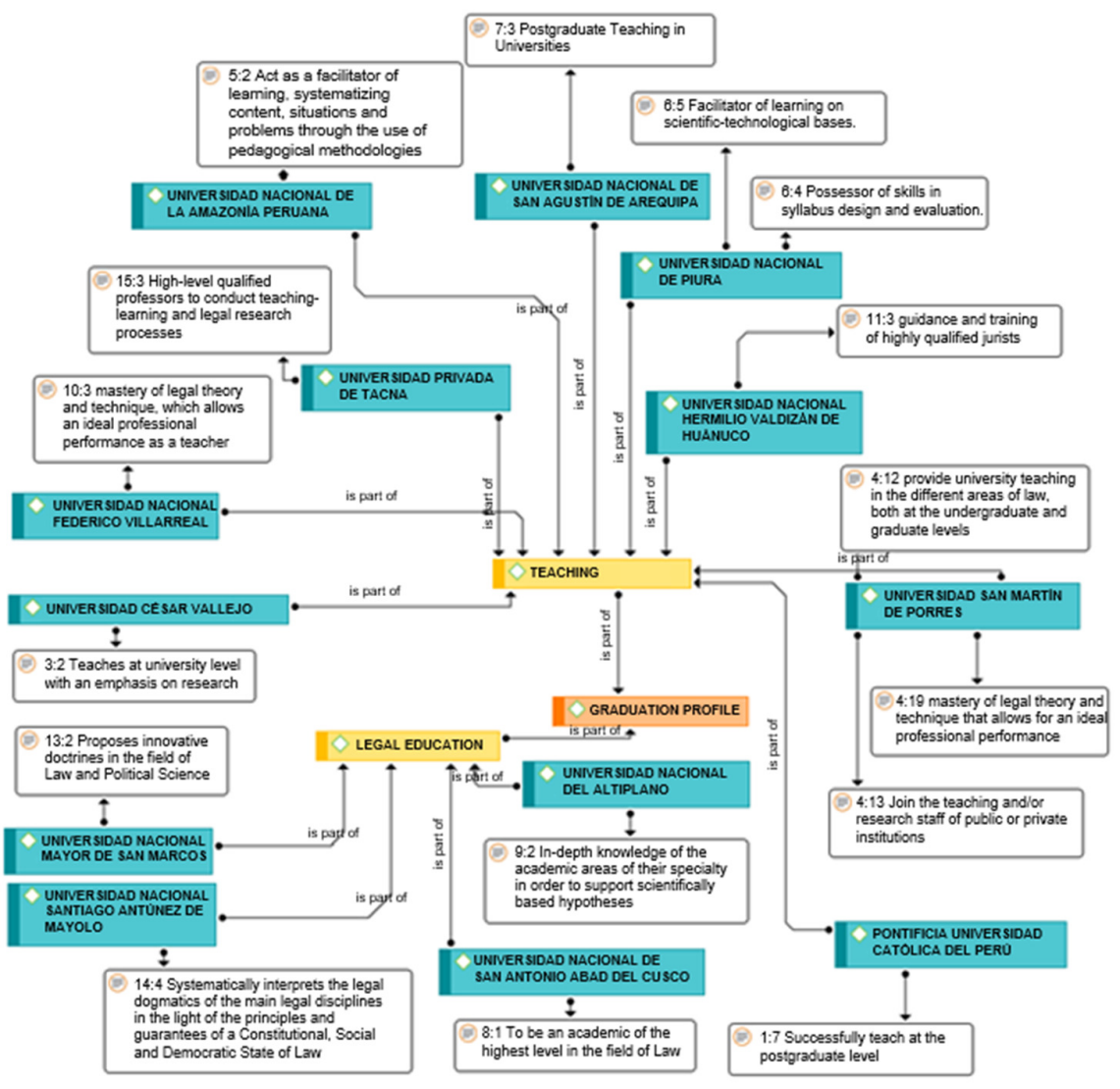

Figure 6: Teaching and legal education

Note. Prepared by the author based on the information analyzed

Figure 6 shows the legal or specialty training and its relationship with teaching or its support in research. Education implies the proposal of innovative doctrines in the legal or political science areas (Universidad Nacional Mayor de San Marcos), the interpretation of legal dogmatics (Universidad Santiago Antúnez de Mayolo), deepening the spatiality to answer hypotheses based on scientific knowledge, (Universidad Nacional del Altiplano), as well as a high academic level in the legal field (Universidad San Antonio Abad del Cusco). Based on professional or scientific training, in this case, it is specified that the teacher successfully teaches at the postgraduate level (Pontificia Universidad Católica del Perú, San Agustín de Arequipa), 
teaches in public or private institutions in under or postgraduate degrees in the various legal specialties (Universidad San Martín de Porres), is prepared to train qualified jurists (Universidad HermilioValdizán de Huánuco), is a facilitator of learning based on technology (Universidad Nacional de Piura,
Universidad Nacional de la Amazonía Peruana), exercises teaching with an emphasis on legal research (Universidad César Vallejo, Universidad Privada de Tacna), and masters a legal theory and techniques in teaching (Universidad Federico Villarreal).

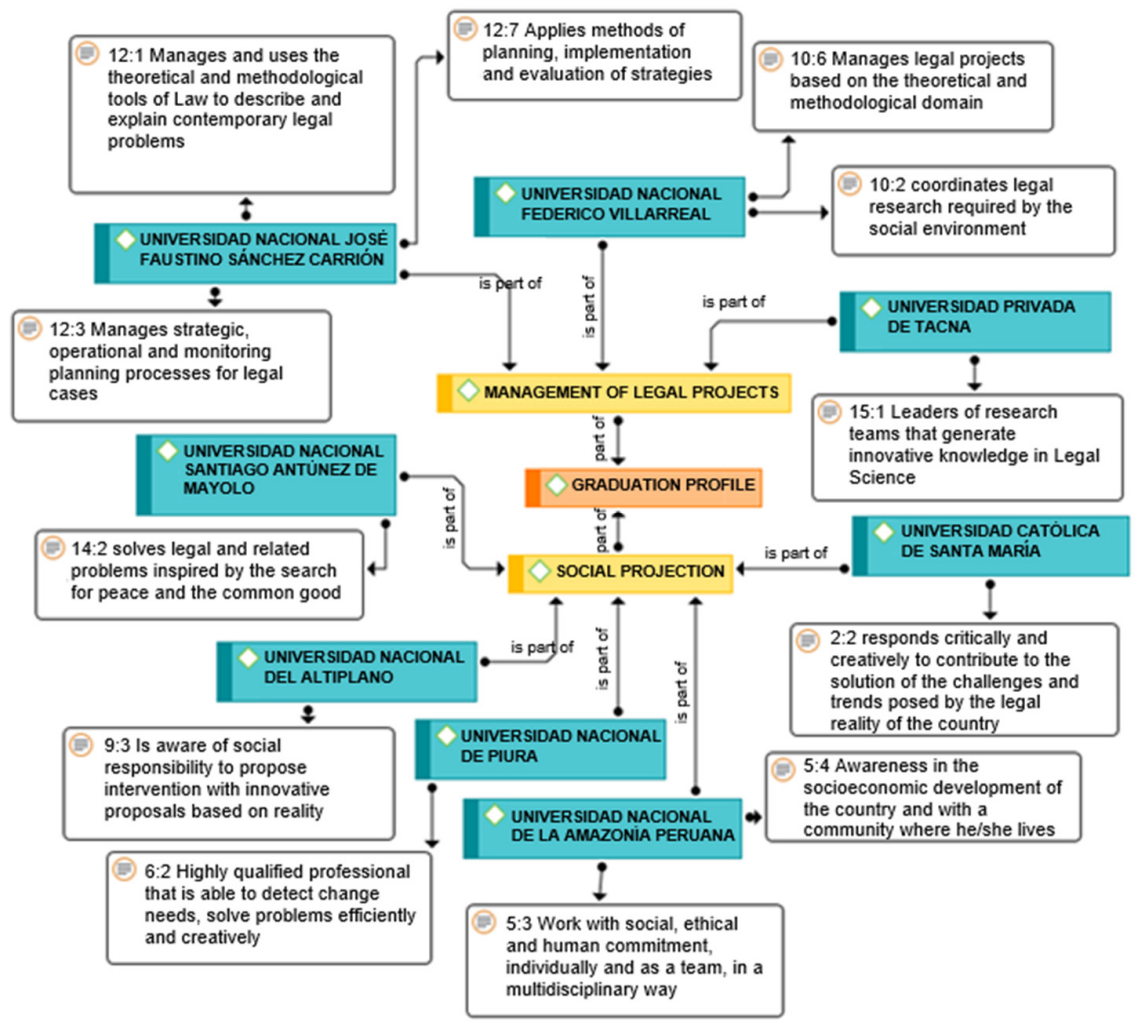

Figure 7: Social projection and management of legal projects

Note. Prepared by the author based on the information analyzed

Figure 7 shows the management and social projection that graduates of the $\mathrm{PhD}$ in law must carry out. Such projection includes: Exercise of leadership in research teams that develop legal knowledge (Universidad Privada de Tacna), and management of legal projects that involve the theoretical and methodological domain of the legal science and respond to the social environment or contemporary legal problems (Universidad Federico Villarreal, Universidad José Faustino Sánchez Carrión). Management is concatenated with social projection and, in this case, it is established that it responds to the solution of the challenges posed by the legal reality of the country (Universidad Católica de Santa María), works with the social commitment or awareness in the economic development of the country (Universidad de la Amazonía Peruana), is qualified to solve problems effectively (Universidad Nacional de Piura), that intervenes with creative proposals consistent with the context or reality (Universidad Nacional del Altiplano), solves legal problems and those related to them (Universidad Nacional Santiago Antúnez de Mayolo). 


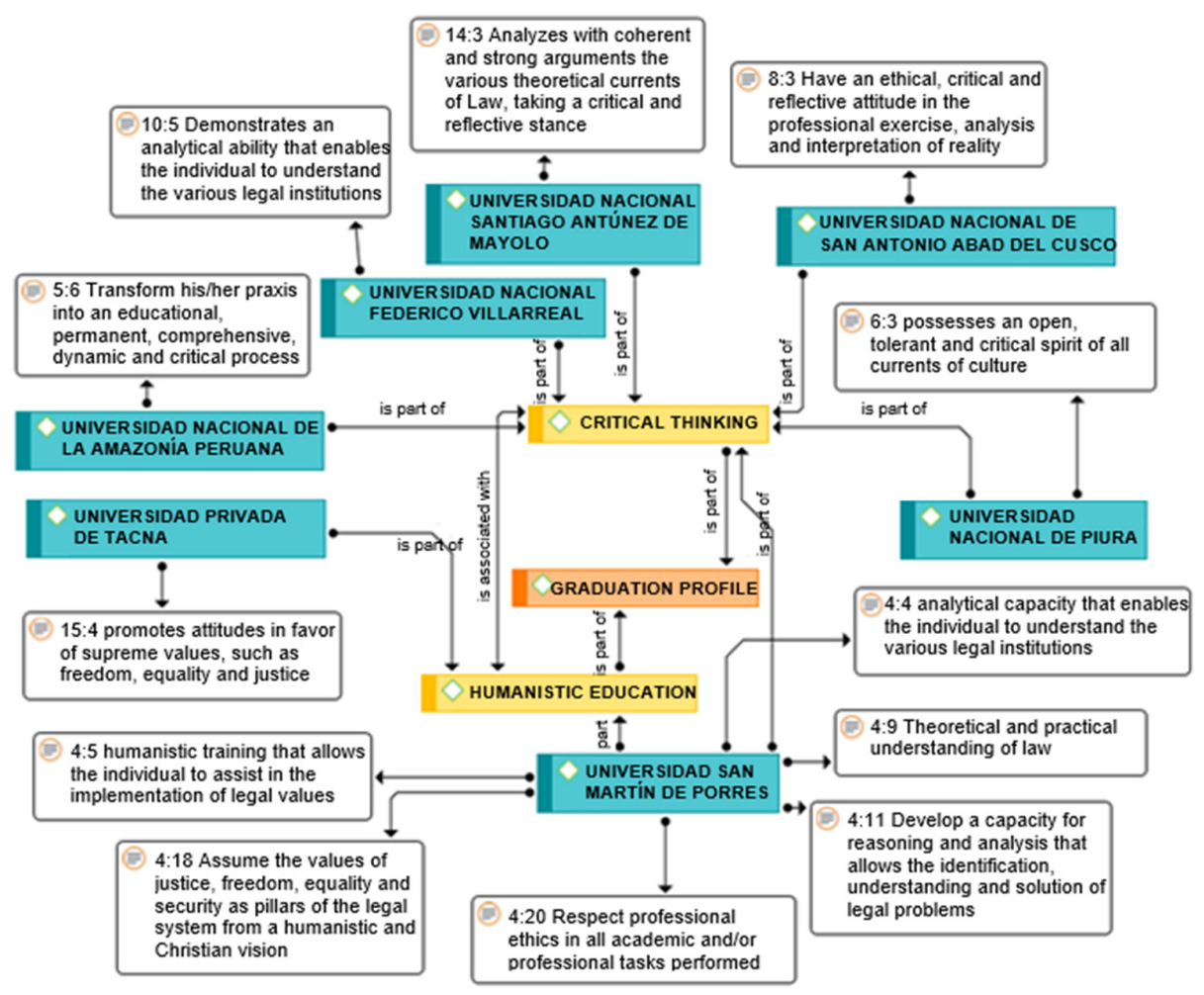

Figure 8: Critical thinking and humanistic education

Note. Prepared by the author based on the information analyzed

Figure 8 shows the development of critical thinking with a focus on assuming a critical stance on the arguments and theoretical currents of law (Universidad Nacional Santiago Antúnez de Loyola), the critical mind on the currents of culture (Universidad Nacional de Piura), the exercise of criticism regarding the professional exercise or educational praxis and on the interpretation of reality (Universidad San Antonio Abad del Cusco, Universidad Nacional de la Amazonía Peruana), as well as the analytical capacity to understand legal institutions and solve legal problems (Universidad Federico Villarreal, Universidad San Martín de Porres). Regarding the humanistic education that is concatenated with the previous one, respect for professional ethics is required in the various activities performed, as well as assuming values of justice from a humanist and Christian view (Universidad San Martín de Porres), promoting attitudes in favor of supreme values such as freedom, equality and justice (Universidad Privada de Tacna). 


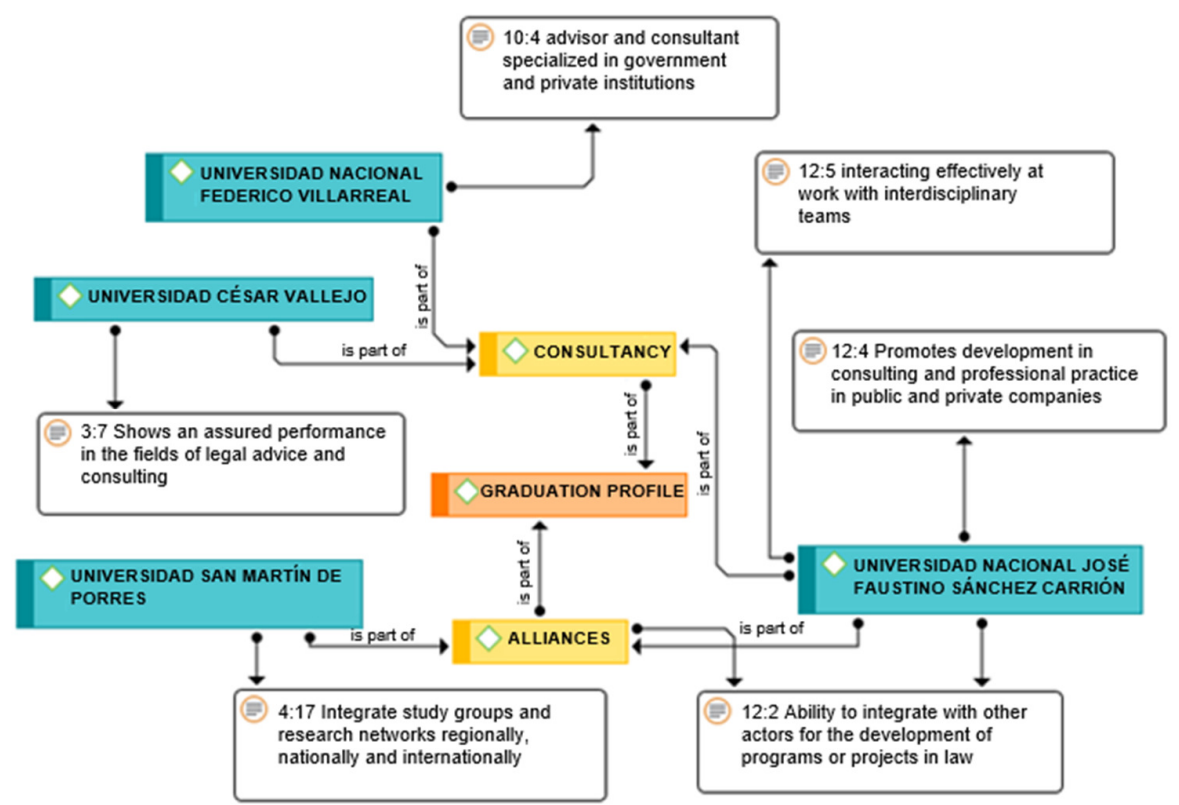

Figure 9: Alliances and consultancies

Note. Prepared by the author based on the information analyzed

In figure 9, the consultancy and alliances that graduates should practice are made explicit. The graduate works with proficiency as an advisor and consultant for governmental or private institutions (Universidad Nacional Federico Villareal, César Vallejo, Universidad José Faustino Sánchez Carrión). Regarding alliances, it is established that a graduate can work together with other actors for the development of programs or projects (Universidad José Faustino Sánchez Carrión), and establish networks or research groups with a national and international scope (Universidad San Martín de Porres).

\section{Discussion}

The results obtained from the analysis of the categories, specifically in the field of research, emphasize the generation and dissemination of knowledge to solve problems related to law or political science. The results showed the qualities of a qualified researcher who must have a solid scientific training, responds to social demands; and develops interdisciplinary research with a national and international scope. Likewise, in the development of the interdisciplinary approach, a researcher must be able to generate alliances or scientific communities with a national and international scope; and apply science to respond to the demands or problems of society. These results are related to the study carried out by Jiménez and Sevillano (2017) who have systematized the characteristics or competencies of the (European) PhD, emphasizing the development of interdisciplinary research, collaboration between national and international entities, and the internationalization of science based on social demands. It also correlates with what was stated by Núñez-Valdés and González (2019), who argue that the PhD focuses on developing excellent quality research with an international impact to contribute to the research community, as well as the use of research methodologies to understand research phenomena. This context is also related to the proposal of Witker (2008) who emphasizes the teaching of a holistic research or proposal that relates the legal phenomenon with the norm, and especially with social facts, to understand them and solve cases or problems. Likewise, they are correlated with the Peruvian University Law No. 30202, which emphasizes the development of an original thesis of an excellent academic rigor. 
Another relevant category is university teaching, based on legal scientific training or political science in order to work during the program in public or private institutions as a learning facilitator. The integration of the legal theory or techniques for teaching is correlated with previous studies, such as that of Solari (2012) which considers that schools or programs that are better positioned require professors who have a PhD. It is also correlated with the contributions of Muñoz (2014), who considers that law schools require the best professors and researchers.

Peruvian PhD programs also highlight management and projection, which require leadership in research teams, management of legal projects that involve legal science to respond to contemporary legal problems, and work with social commitment. These approaches are related to what has been studied by Jiménez (2017), which requires designing and conducting scientific research or the creation of knowledge, and which encourages the advancement of science and technology. On the other hand, it is concatenated with the study by Rueda, Acosta and Cueva (2020) who establish that the projection allows obtaining knowledge and solving environmental problems based on research.

Another relevant point is the category of critical thinking and humanistic education. The first emphasizes developing a critical stance on the legal arguments and currents. These are related to what Clavijo (2014) proposed, as he emphasizes that the student must have reasoning and legal argumentation. Along the same lines, Bezanilla, Poblete, Fernández, Arranz and Campo (2018) establish that critical thinking allows the student to argue and question, which also consolidates their education. Regarding humanistic education, it is specified that it provides values of justice with a humanistic vision and that it promotes the practice of supreme values that are concatenated with the proposals of Sánchez and Pérez (2017), who establish that humanist education "provides humans with cognitive elements essential to better understand the world to obtain an aesthetic education, together with the refinement of sensitivity, and the improvement of moral and ethical qualities".

Finally, the consultancies and alliances established by the graduate programs through their graduates allow them to interact in order to solve problems in their environment, taking into account the aspects that they have learned in the $\mathrm{PhD}$ process or education.

Therefore, the results and the theoretical foundations can answer the questions formulated at the beginning of the study regarding the categories that have predominance, which according to the analysis carried out, are research and teaching. Research also serves as the basis for other categories; for example, it serves as a foundation for teaching, and an execution of social projection that is oriented to solving problems based on social needs. It also serves as the basis for the argumentation or critical evaluation of scientific knowledge and its application; also to manage legal science. The categories that have less emphasis on graduation profiles are the development of consultancies and alliances with other institutions.

\section{Conclusions}

There is no uniformity or similarity between the graduate profiles of law faculties in Peruvian Universities, unlike the European model.

The predominant category is research in its various manifestations: specialty, teaching, problem solving, with an interdisciplinary approach, as well as national and international scope; followed by the teaching category based on research, and science. This is developed in public and private institutions.

Other relevant categories are critical thinking and humanistic education that allow questioning, analysis of the development of science and solving problems of the environment. These contemporary or complex social problems are solved also from the humanist perspective, precisely by resorting to the formation of the law PhDs, based on the experience and knowledge acquired. 
Finally, there is the creation of alliances, networks or teams to develop science within a national and international scope. As for consultancies, although it is a category that is not specified much in the plans, it is relevant because it allows the management of government or private institutions.

\section{References}

- Angarita, J. and Mateo, M. (2011). El reto de acometer un Doctorado: Modelos de Doctorado y Tesis Doctoral (The Challenge of Undertaking a Phd: Phd Models and Doctoral Thesis). Orbis. Scientific e-journal of Human Sciences, $7(20)$,

149-177.

https://www.redalyc.org/articulo.oa?i $\mathrm{d}=70922149006$.

- Alzate-Gallego, Y., Gutiérrez-Giraldo, M.,and Orozco-Vallejo, M. (2018). La proyección social universitariacomoacto de donación y hospitalidad (The University Social Outreach as an Action of Endowment and Hospitality). Revista de Investigaciones UCM, 18(32), 106-118. http://www.revistas.ucm.edu.co/ojs/i ndex.php/revista/article/view/117/p df\#.

- Bezanilla, M., Poblete, M., Fernández, D., Arranz, S., and Campo, L. (2018). El PensamientoCríticodesde Perspectiva de los DocentesUniversitarios (Critical Thinking from the Perspective of University Teachers). Estudiospedagógicos (Valdivia), 44(1), 89-113.

https://dx.doi.org/10.4067/S071807052018000100089.

- Bozzo, S. and Remeseiro, R. (2017). El sistema de acreditación de postgradosen Chile (The postgraduate accreditation system in Chile). EDUCATION AND LAW MAGAZINE, 15, 1-23.

https://doi.org/10.1344/REYD2017.1 5.21104.

- Cázares, C. (2017). Inclusión de las TIC y la enseñanzaen la investigaciónjurídicaenelposgradoen derecho a nivelespecialidad de la UNAM (Inclusion of ICT and teaching in legal research in postgraduate law at UNAM).
RevistaPedagogíaUniversitaria y Didáctica del Derecho, 4(1), 254-297. https://doi.org/10.5354/07195885.2017.46256.

- Clavijo, D. (2014). El enfoque de competenciasen la formación del abogado para elsiglo XXI (The focus of competence in the formation of attorney for the XXI century). Justice, 27 , 185-212. http://www.scielo.org.co/pdf/just/n2 7/n27a11.pdf.

- Gracés-Frettel, M. and Santoya-Montes, Y. (2013). La formación doctoral: expectativas

retosdesdeelcontextocolombiano

(Doctoral education: expectations and challenges within the Colombian context). Education and Educators, 16(2), 283-294. https://www.redalyc.org/articulo.oa?i $\mathrm{d}=834 / 83428615005$.

- Fiftal, L. (2016). How to Secure Your First Academic Job Out of Graduate School. Journal of Criminal Justice Education, 27(2), 160- 174. https://doi.org/10.1080/10511253.20 15.1128702 .

- González, H. (2018). LA INVESTIGACIÓN EN LOS PLANES DE ESTUDIOS DOCTORALES EN DERECHO DE UNIVERSIDADES PERUANAS (THE RESEARCH ON THE DOCTORATE STUDIES ABOUT LAWS OF PERUVIAN UNIVERSITIES). Acta Jurídica Peruana, 1(2), 211-236. http://revistas.autonoma.edu.pe/index .php/AJP/article/view/113/91.

- Hermida, J. (2018). La acreditación de las carreras de gradoen Derecho en la Argentina a la luz de la experienciainternacional

(Accreditation of Undergraduate law Programs in Argentina in light of the International Experience). Academia. Revistasobreenseñanza del Derecho, 16(31), 175-201. http://www.derecho.uba.ar/publicacio nes/rev_academia/revistas/31/laacreditacion-de-las-carreras-de-gradoen-derecho-en-la-argentina-a-la-luzde-la-experiencia-internacional.pdf.

- Herrera-Añazco, P. and Alhuay-Quispe, J. (2020). Actividades de investigación de 
doctoresperuanosencienciasmédicas y de la salud (Research activities performed by Peruvian doctorate in medical and health sciences). RevistaCubana de InformaciónenCiencias de la Salud, 31(1), 1-14. http://scielo.sld.cu/scielo.php?script=s ci_arttext\&pid=S230721132020000100008\&lng=es.

- Jiménez-Ramírez, M. (2017). Los nuevosestudios de doctoradoenEspaña: avances y retos para suconvergencia con Europa (New doctoral studies in Spain: progress and challenges for covergence with Europe). Revistaiberoamericana de educación superior, 8(21), 123-137. http://www.scielo.org.mx/scielo.php?s cript=sci_arttext\&pid=S2007-

28722017000100123\&lng=es\&tlng=es

- Jiménez-Ramírez, M. and Sevilla, D. (2017). El doctoradoenEspaña: estudio e implicaciones dentro del espacioeuropeo de la educación superior (The Doctorate in Spain: study and implications within the European Higher Education Area). Lusófona de EducaçãoJournal, 35, 31-65. https://doi.org/10.24140/issn.16457250.rle35.03.

- Jiménez, M.

Convergenciaeuropea internacionalización del Doctorado: panorámicasobre las tendencias de cambioenEspaña (European convergence and internationalization of Doctoral Studies: An overview of trends towards change in Spain). Estudiospedagógicos (Valdivia), 43(1), 405-422.

https://dx.doi.org/10.4067/S071807052017000100023.

- Kleck, G. and Mims, B. (2017). Article Productivity Among the Faculty of Criminology and Criminal Justice Doctoral Programs, 2010-2014. Journal of Criminal Justice Education, 28(4), 467487.

https://doi.org/10.1080/10511253.20 16.1146008.

- University Act no.30220 (2014). http://ojs.uc.cl/index.php/Rchd/articl e/view/23247/18855.
- Llopis, P. (2019). Estudiantes de cienciasjurídicas y trabajos de investigación: análisis de los derechos de propiedadintelectualsobreel TFG, el TFM y la Tesis Doctoral (Legal Science Students and Research Papers: Analysis of Intellectual Property Rights on the Final Degree Project, the Master's Final Project and the Doctoral Thesis). REVISTA DE EDUCACIÓN Y DERECHO, 20, 1-22. https://revistes.ub.edu/index.php/RE D/article/view/29696/30024\%20(tesi s\%20doctoral).

- Manta, S., Sandreschi, P., Cardoso, A., Benedetti, T., Farias, G., Resende, R., Nascimento, J. (2019). Profile of the graduates of the phd course of the postgraduate program in physical education: a case study at Federal University of Santa Catarina (2006 to 2018). Rev Bras CineantropomDesempenho Hum, 22, 117. http://dx.doi.org/10.1590/19800037.2020v22e66261.

- Manley, S. (2019). Degree (Un)Equivalencies: The Confounding Case of the Juris Doctor. Journal of Legal Education, 68(2), 392- 415. https://jle.aals.org/cgi/viewcontent.cg i? article $=1624 \&$ context $=$ home .

- Muñoz, F. (2014). ¿Hacia la academización de las facultades de derecho en Chile? Un análisisteórico y comparado del conflicto de las profesiones". Revista de Derecho, 27(1), 9-25.

Núñez-Valdés, K. y González, J. (2019). Perfil de egreso doctoral: una propuestadesdeelanálisis documental y las expectativas de los doctorandos (Doctoral graduation profile: a proposal from documentary analysis and doctoral students' expectations). IE Revista de investigacióneducativa de la REDIECH, 10(18), 161-175. https://dx.doi.org/10.33010/ie_rie_re diech.v10i18.604.

- Pavó, R. (2015). La investigaciónjurídica de postgradoenLatinoamérica (Postgraduate legal research in Latin America). Tla-melaua, 9(38), 72-93. http://www.scielo.org.mx/scielo.php?s cript=sci_arttext\&pid=S1870- 
$69162015000200072 \& \operatorname{lng}=e s \& t \operatorname{lng}=e s$

- Pérez Hurtado, L. (2018). EL SISTEMA DE ENSEÑANZA DEL DERECHO Y ACCESO A LAS PROFESIONES JURÍDICAS EN ALEMANIA: LECCIONES PARA EL DEBATE EN MÉXICO (THE SYSTEM OF LAW EDUCATION AND ACCESS TO THE LEGAL PROFESSIONS IN GERMANY: LESSONS FOR DISCUSSION IN MEXICO). BoletínMexicano de Derecho Comparado, 1(151), 263-311. http://dx.doi.org/10.22201/iij.244848 73e.2018.151.12295.

- Pérez, R. (2018). DE HARVARD A STANFORD. SOBRE LA HISTORIA DE LA EDUCACIÓN JURÍDICA EN LOS ESTADOS UNIDOS (FROM HARVARD TO STANFORD. HISTORY OF LEGAL EDUCATION IN THE UNITED STATES). BoletínMexicano de Derecho Comparado, 1(151), 313-358. http://dx.doi.org/10.22201/iij.244848 73e.2018.151.12296.

- Pontificia Universidad Católica del Perú (s.f.). Graduate Profile. https://posgrado.pucp.edu.pe/doctora do/derecho/perfil-graduado/.

- Rueda, I., Acosta, B., and Cueva, F. (2020). LAS UNIVERSIDADES Y SUS PRÁCTICAS DE VINCULACIÓN CON LA SOCIEDAD (UNIVERSITIES AND THEIR PRACTICES OF OUTREARCH WITH SOCIETY). Educação \&Sociedade, 41, e218154.

https://doi.org/10.1590/es.218154.

- Sánchez, V. and Pérez, M. (2017). LA FORMACIÓN HUMANISTA: UN ENCARGO PARA LA EDUCACIÓN (HUMANIST FORMATION. A COMMISSION FOR EDUCATION). Revista Universidad y Sociedad, 9(3), 265-269.

http://scielo.sld.cu/scielo.php?script=s ci_arttext\&pid=S2218-

36202017000300041\&lng=es\&tlng=es

- Sanromán, R. and Morales, L. (2016). La educación por competenciasen el campo del derecho (The education competencies in the field of law). Boletínmexicano de derecho comparado, 49(146), 179-203. http://www.scielo.org.mx/scielo.php?s cript=sci_arttext\&pid=S0041-
$86332016000200179 \& \operatorname{lng}=e s \& t \operatorname{lng}=e s$

- Universidad Nacional del Altiplano (s.f.). Graduate Profile. http://posgradounap.pe/doctoradoen-derecho/.

- Universidad Nacional de San Agustín de Arequipa (s.f.). Graduate Profile. http://posgrado.unsa.edu.pe/escuela/ doctorado-en-derecho/.

- Universidad Nacional de la Amazonía Peruana (s.f.) Graduate Profile. https://www.unapiquitos.edu.pe/post grado/escuela/descargas/010P_derecho-ciencia-politica/P91_PLANY-MALLA_DOCTORADO-ENDERECHO.pdf.

- Universidad Católica de Santa María (s.f.). Graduate Profile. https://www.ucsm.edu.pe/epostgrado/dp-ciencias-juridicas/.

- Universidad César Vallejo SAC (s.f.). Graduate Profile. https://www.ucv.edu.pe/posgrado/do ctorado/derecho/lima-norte.

- Universidad Nacional San Antonio Abad del Cusco (s.f.). Postgraduate Profile. http://postgrado.unsaac.edu.pe/docto rados/doc der.

- Universidad Nacional HermilioValdizán de Huánuco (s.f.). Graduate Profile. http://www.epgunheval.edu.pe/docto rado/doctorado-en-derecho/.

- Universidad Privada de Tacna, Penal y Política Criminal (s.f.). Graduate Profile. http://postgrado.upt.edu.pe/postgrad o/doctorado/doctorado-en-derecho/.

- Universidad Nacional Santiago Antúnez de Mayolo (s.f.). Graduates of the Doctorate in Law and Political Science will have the following competencies and abilities. https://www.tuni.pe/programas?page $=14 \&$ term $=$ DOCTORADO.

- Universidad Nacional José Faustino Sánchez Carrión (s.f.). Graduate Competency Profile. https://unjfsc.edu.pe/posgrado/docto rados/\#derecho.

- Universidad Nacional de Piura (s.f.). Graduate Profile. http://epg.unp.edu.pe/eposgrado/doct orados/prododecip/.

- Universidad San Martin de Porres (s.f.) Ph.D. Graduate Profile. 
https://derecho.usmp.edu.pe/posgrad o/doctorado/Perfil_\%20academico_do ctorado.html.

- Universidad Nacional Federico Villarreal (s.f.). Graduate Profile. http://www.unfv.edu.pe/eupg/index.p $\mathrm{hp} /$ doctorados/derecho-y-cienciapolitica/derecho.

- Universidad Nacional de San Marcos (s.f.). Graduate Profile. https://www.tuni.pe/universidades?p age $=10$.

- Vides, M., Gómez, M.,and Pérez, L. (2011). The American Way: Los abogados latinoamericanoscomo estudiantes de maestríaenEstados Unidos de América (The American Way. Latin American Lawyers as Graduate
Students in the United States). Boletínmexicano de derecho comparado, 44(130), 351-402. http://www.scielo.org.mx/scielo.php?s cript $=$ sci_arttext $\&$ pid $=$ S0041

86332011000100011\&lng=es\&tlng=es

- Vila, D. and Hernández, H. (2013). Propuesta de un perfilprofesional para eldiseño del doctorado curricular colaborativoenestomatología (Proposal of a professional profile for the design of the collaborative curricular doctorate in stomatology). Rev CubanaEstomatol, 50(1), 59-64. http://www.revestomatologia.sld.cu/i ndex.php/est/article/view/308/13. 